\title{
GLACIOLOGICAL RESEARCH SUB-COMMITTEE
}

The Glaciological Research Sub-Committee of the British Glaciological Society has recently completed its first year of activity. The following is an extract from the first annual report tendered by the Sub-Committee to the Committee of the British Glaciological Society:

The Glaciological Research Sub-Committee was constituted by the Committee of the British Glaciological Society on 2 December 1955. The members of the Sub-Committee appointed were: The Chairman of the Committee of the B.G.S. (ex officio), J. W. Glen, G. de Q. Robin, C. W. M. Swithinbank, W. H. Ward. The Sub-Committee was given the following terms of reference and constitution :

Constitution of Sub-Committee. The members shall be elected by the main Committee and be five in number. They shall serve for one year, but may be re-elected. The SubCommittee may co-opt members for any period not greater than one year. Three members form a quorum. Administrative expenses shall be paid by the Society. The Sub-Committee may reply to requests for advice in glaciological research without reference to the main Committee, but shall seek the approval of the main Committee before initiating research. The Sub-Committee shall not have power to give the name of the Society to research or an expedition.

Terms of Reference. To encourage and advise on glaciological research and to report annually to the main Committee.

On IIth October $195^{6}$ J. F. Nye was co-opted to the Sub-Committee.

\section{Work of the Sub-Committee}

The Sub-Committee has held four meetings and has dealt with many requests by correspondence. As the majority of such requests come from small expeditions, primarily composed of undergraduates or junior graduates, it was felt that a short series of notes on the general type of glaciological work that should be done by expeditions would be useful, and would avoid unnecessary duplication in letters to enquirers. With these aims in mind, the Sub-Committee has prepared a duplicated document entitled "Measurements required on a glacier in an area which is unknown and unmapped." This is referred to as "Technical Note No. r." The Sub-Committee has also made progress with a second note entitled "Measurements required on a glacier in a known area, e.g. the Alps." Further notes are contemplated.

\section{Requests for Advice}

Requests for advice have been received from ten expeditions visiting Norway, Kashmir, Iceland, Africa and Antarctica. Most of these enquirers have been supplied with a copy of Technical Note No. I, and with other, more particular, advice.

\section{Publication of Results}

The Sub-Committee has also received enquiries concerning the most desirable form of publication of the results of small expeditions. It is felt that many expeditions have results which, while they do not merit the expense of full printed publication, may be of great value, not least to subsequent expeditions visiting the area. It is proposed that the British Glaciological Society should express its willingness to house any duplicated reports that may be prepared, and to publish a short statement of the existence of such data. If expeditions can afford to duplicate a stock of copies, the Society might also undertake to announce the availability of these to those interested. All expeditions should be encouraged to prepare such a report, and to send copies to the Society and also to an organisation in the country in which the work is done.

The annual report from which the above are extracts was received and approved by the Committee of the British Glaciological Society earlier this year. A new Committee has been 
appointed, consisting of the Chairman of the B.G.S. (W. V. Lewis), R. J. Adie, J. W. Glen, J. F. Nye, and W. H. Ward. The Sub-Committee will be pleased to receive requests for advice from members, which should be addressed either to any member of the Sub-Committee personally, or to the Secretary of the British Glaciological. Society, c/o Scott Polar Research Institute, Lensfield Road, Cambridge. Expeditions wishing to deposit duplicated reports of their activities should send them to the Secretary at the above address.

\section{GLACIER MECHAN ICS}

\section{Comments on Professor L. Lliboutry's paper* \\ By J. F. NYE \\ (University of Bristol)}

THE Editor has kindly invited me to comment on Professor Lliboutry's recent paper, and I am glad to do so in the hope of clarifying certain differences between my own ideas on glacier flow and those which Lliboutry is putting forward. I think it is worth while trying to do this because there is evidently already much common ground between us.

I begin by quoting the English summary in full:

The mechanics of a glacier is accounted for with a minimum of assumptions. Two facts which seemed inconsistent with Nye's theory are thus explained:

(I) Too gentle slopes at the centre of the Greenland Icecap (northern part). That is because the ice is flowing off from the icecap at the border only, being stagnant at the centre. Opposite to the classical scheme of an "evacuating glacier," the author introduces the scheme of a "reservoir glacier."

(2) Finite gradient of the slope at the front. A more accurate differential equation for the equilibrium profile is established and integrated by successive approximations. This equation leads for the slope at the front, relative to the bed, to an universal value : $0.568=\operatorname{tg} 29^{\circ} 36^{\prime}$, which conforms to the observed values, specially at the Thule ramp.

It is then explained why the blue bands and the shear moraines get very close to the stream-lines near the front. A qualitative explanation of their courses is given. Refuting Nielsen and Stockton's calculations, the author enters upon an approximate calculation of the velocities near the front, according to the theory of perfect plasticity.

Lastly, new general cases of extensive flow are indicated, and Nye's theory on crevasses partially denied.

It is first necessary to clear up a misunderstanding in relation to point (2) of the summary. The slope of a glacier at the snout is indeed something that needs analysis. But the theory I have expressed has never attempted to cover this region of a glacier, because it is precisely here that the approximations are recognized to break down. It is a misunderstanding therefore to suppose that the "finite gradient of the slope at the front" is inconsistent with the theory.

Coming now to Lliboutry's analysis, the first hypothesis (p. 248) is that in the model glacier under consideration the longitudinal stress $\sigma_{x}$ is everywhere equal to "the hydrostatic pressure $\rho g . \Delta Z, \Delta Z$ being the vertical distance to the free surface." This is introduced only as a first approximation and, as such, is free from objection. Lliboutry contrasts it with the slightly different hypothesis which I have used ( $\rho g . M A$ in his Fig. I), but, in fact, to the first approximation our hypotheses are identical. It is true that in the second approximation they are different, but this is beside the point, since both of us agree that our hypotheses are only introduced at this point as being true to the first approximation. Lliboutry goes on to derive his leading formula (2) for the shear stress $\tau_{0}$ on the glacier bed:

$$
\tau_{0}=\rho g \frac{S}{p} \tan \alpha \cos \beta,
$$

where $p$ is the perimeter of a cross section, $\alpha$ is the slope of the surface, and $\beta$ is the slope of the bed. ( $\mathrm{S}$ is undefined but is evidently the area of cross section perpendicular to the bed.) For small angles, as he points out, this reduces to the formula I have given, namely

$$
\tau_{0}=\rho g \frac{\mathrm{S}}{p} \alpha \text {. }
$$

- L. Lliboutry. La mécanique des glaciers en particulier au voisinage de leur front. Annales de Géophysique, Tom. r2, Fasc. 4, 1956, p. $245-76$. 